\title{
Circulating leptin during ovine pregnancy in relation to maternal nutrition, body composition and pregnancy outcome
}

\author{
L Thomas, J M Wallace, R P Aitken, J G Mercer, P Trayhurn \\ and $\mathbf{N}$ Hoggard
}

\begin{abstract}
Aberdeen Centre for Energy Regulation and Obesity, Rowett Research Institute, Greenburn Road, Bucksburn, Aberdeen AB21 9SB, UK
(Requests for offprints should be addressed to L Thomas, Molecular Physiology, Rowett Research Institute, Greenburn Road, Bucksburn, Aberdeen AB21 9SB, UK; Email: L.Thomas@rri.sari.ac.uk)

(P Trayhurn is now at Institute for Nutrition Research, University of Oslo, PO Box 1046, Blindern, N-0316 Oslo, Norway)
\end{abstract}

\begin{abstract}
This study examined the pattern of circulating leptin in age-matched sheep during adolescent pregnancy, and its relationship with maternal dietary intake, body composition and tissue expression of the leptin gene. Overfeeding the adolescent pregnant ewe results in rapid maternal growth at the expense of the placenta, leading to growth restriction in the fetus, compared with normal fed controls.

Our results demonstrate that, in the adolescent ewe, overfeeding throughout pregnancy was associated with higher maternal leptin concentrations, when compared with moderately fed controls $(P<0 \cdot 05)$, with no peak in circulating leptin towards the end of pregnancy. There was a close correlation between indices of body composition and circulating leptin levels at day 104 of gestation and at term $(P<0 \cdot 03)$. Further, when the dietary intake was switched from moderate to high, or high to moderate, at day 50 of gestation, circulating leptin levels changed rapidly, in parallel with the changes in dietary intake. Leptin mRNA levels and leptin protein in perirenal adipose tissue samples, taken at day 128 of gestation, were higher in overfed dams $(P<0 \cdot 04)$, suggesting that adipose
\end{abstract}

tissue was the source of the increase in circulating leptin in the overnourished ewes. Leptin protein was also detected in placenta but leptin gene expression was negligible. However, leptin receptor gene expression was detected in the ovine placenta, suggesting that the placenta is a target organ for leptin. A negative association existed between maternal circulating leptin and fetal birth weight, placental/cotyledon weight and cotyledon number.

In conclusion, in this particular ovine model, hyperleptinaemia was not observed during late pregnancy. Instead, circulating leptin concentrations reflected increased levels of leptin secretion by adipose tissue primarily as a result of the increase in body fat deposition, due to overfeeding. However, there appears to be a direct effect of overfeeding, particularly in the short term. In the nutritional switch-over study, circulating leptin concentrations changed within $48 \mathrm{~h}$ of the change in dietary intake. The presence of leptin protein and leptin receptor gene expression in the placenta suggests that leptin could be involved in nutrient partitioning during placental and/or fetal development.

Journal of Endocrinology (2001) 169, 465-476

\section{Introduction}

Leptin $(\mathrm{OB})$, the protein product of the $o b$ gene, is a $16 \mathrm{kDa}$ hormone whose principal site of synthesis is white adipose tissue, although expression of leptin now appears to be much more widespread; the stomach, muscle, placenta and fetal tissues have all been shown to express the leptin gene (Hoggard et al. 1997, 2000, Masuzaki et al. 1997, Wang et al. 1998, Bado et al. 1998). Leptin is considered to be a signalling molecule to the brain in the regulation of whole-body energy balance. However, it is increasingly recognized that leptin has a number of other functions (for review see Harris 2000).

Reproduction is one such area where a role for leptin has been established (for review see Hoggard et al. 1998).
Administration of leptin can restore the fertility of leptindeficient ob/ob mice (Chehab et al. 1996) and accelerate the onset of puberty in normal female rodents (Ahima et al. 1997, Chehab et al. 1997). Moreover, leptin rises in the maternal circulation towards the end of pregnancy in humans and rodents, with a fall in titre to below prepregnancy levels at around birth. In the mouse, serum leptin has been reported to increase 25-fold (Tomimatsu et al. 1997) in the maternal circulation and this compares with a threefold reported rise in humans (Hardie et al. 1997) and rats (Chien et al. 1997). Although maternal fat deposition increases during pregnancy, in pregnant women, at least, the gestational increase in circulating leptin does not appear to be correlated with changes in maternal body mass index (Lage et al. 1999). 
One possible explanation for the increase in leptin towards the end of pregnancy is synthesis by the placenta. The relative contribution of adipose and placental-derived leptin to circulating levels in the rodent is uncertain. The placenta has been shown to express both the leptin and leptin receptor genes (Hoggard et al. 1997, Masuzaki et al. 1997, Henson et al. 1998, Bodner et al. 1999). Interestingly, in humans, placental leptin expression in growthrestricted pregnancies is lower when compared with diabetic pregnancies and, relative to controls, the growthrestricted pregnancies have lower placental and cord blood leptin concentrations (Lea et al. 2000). However, there are clear differences in the relative levels of placental leptin expression between species (Hoggard et al. 1997, Masuzaki et al. 1997). In addition, the human leptin gene has a placental-specific upstream enhancer, suggesting that placental leptin is differentially regulated from leptin of adipose origin (Bi et al. 1997). There are at least two other explanations for the increase in leptin towards the end of pregnancy: increased secretion by specific adipose tissue depots (Tomimatsu et al. 1997), or the release of the soluble leptin receptor $(\mathrm{Ob}-\mathrm{Re})$ by placental membrane shedding (Gavrilova et al. 1997). However, the large increase in bound circulating leptin observed during late pregnancy in mice does not occur in humans or rats (Gavrilova et al. 1997). Indeed, in the human, levels of soluble receptor are reported to fall between weeks 20 and 30 of gestation (Lewandowski et al. 1999).

To examine some of these issues, we have utilized the nutritionally sensitive adolescent ewe model which consistently produces perturbations in placental and fetal growth. In this paradoxical model, overfeeding the adolescent pregnant ewe results in rapid maternal growth at the expense of the growing fetus (Wallace et al. 1996). This leads to growth restriction in the placenta and fetus, compared with moderately fed adolescents of equivalent age. This model provides us with a highly controlled framework in which to study the response of leptin to nutritional changes during pregnancy. The primary aim of the study was to establish the pattern of circulating leptin in age-matched sheep during pregnancy, and its relationship with maternal dietary intake, body composition and tissue expression of leptin. We also aimed to establish whether the ovine placenta, in common with rodents and humans, is a significant source of leptin.

\section{Materials and Methods}

\section{Adolescent pregnant ewe model}

All procedures were approved by the Home Office under the UK Animals Scientific Procedures Act of 1986. The model and experimental design have been described in detail elsewhere (Wallace et al. 1999). Briefly, adult Border Leicester $\times$ Scottish Blackface ewes (Greyface) were superovulated and inseminated with semen collected from a single sire (Dorset Horn). The recovered embryos were transferred, in singleton, to recipient adolescent ewes (Suffolk or Dorset Horn $\times$ Greyface). All animals were housed in individual pens under natural lighting conditions at the Rowett Research Institute. At embryo transfer, the ewe lambs were peripubertal, $190 \pm 1 \cdot 5$ days old and weighed $43 \cdot 7 \pm 0 \cdot 27 \mathrm{~kg}$ (means \pm s.E.M.). Immediately after embryo transfer the adolescent ewes were allocated to one of two dietary treatments on the basis of live weight, body condition score and ovulation rate at the time of transfer. The ewes were individually offered either a high $(\mathrm{H}, n=22)$ or moderate level (M, $n=22)$ of a complete diet to promote rapid ( $\sim 300 \mathrm{~g} /$ day) or low ( $\sim 55 \mathrm{~g} /$ day) maternal growth rates. The diet was offered in two equal rations at 0800 and $1600 \mathrm{~h}$ each day and supplied 10.23 MJ of metabolizable energy and $137 \mathrm{~g}$ crude protein per kg dry matter. At day 50 of gestation a subset of the ewes in each group had their dietary intake switched. This gave rise to four treatment groups: MM, $\mathrm{HH}, \mathrm{MH}$ and HM. After day 100 of gestation the feed intake of the moderate intake groups (MM and HM) was adjusted weekly to maintain body condition and to meet the increasing nutrient demands of the developing fetus during the final third of gestation. Body condition score was assessed on a 5 point scale where $1=$ emaciated and $5=$ obese (based on the criteria of Russel et al. 1969). On day 104 of gestation a subset of ewes from all four nutritional treatments ( $n=4$ or 5 per group) were killed by an i.v. injection of an overdose of sodium pentobarbitone. The gravid uterus was removed and fetal and placental weights recorded (Wallace et al. 1999). The maternal body was dissected and separated into carcass and non-carcass components which were minced. Samples of each were freeze-dried and the fat content determined by the chloroform-methanol method (Atkinson et al. 1972). In the remaining ewes, pregnancy outcome was determined after spontaneous vaginal delivery at term (Wallace et al. 1999). Weekly maternal blood samples were analysed for leptin concentrations.

Tissue samples were also collected from a separate study (Wallace et al. 2000) in which adolescent ewes underwent the same basic nutritional treatments $(\mathrm{M}$ and $\mathrm{H})$ resulting in similar degrees of placental and fetal growth restriction as previously reported (Wallace et al. 1996). The animals also exhibited similar changes in liveweight and body condition score. At day 128 of gestation, placentomes, with fetal cotyledon and maternal caruncle intact, and perirenal adipose tissue samples were collected, snap frozen over liquid nitrogen-chilled isopentane and stored at $-70{ }^{\circ} \mathrm{C}$. RNA was subsequently extracted from the adipose tissue samples and leptin gene expression determined by nuclease protection assay. RNA and protein were extracted from the placentomes. Leptin and leptin receptor gene expression determined by nuclease protection assay and RT-PCR and protein by enzyme-linked immunosorbent assay (ELISA) and Western blotting. In 
addition, placentomes collected at day 128 of gestation were fixed in $4 \%$ paraformaldehyde and then embedded in paraffin wax. These tissue blocks were then stored at room temperature prior to sectioning for immunocytochemistry to determine the presence of leptin protein.

\section{Ovine-specific sandwich ELISA}

To determine circulating ovine leptin concentrations, an ovine-specific solid-phase sandwich ELISA was developed. Antibodies were raised commercially in rabbits and chickens against recombinant ovine leptin (Gertler et al. 1998). The animals were immunized with recombinant ovine leptin dissolved in Freund's complete adjuvant. Animals were subsequently boosted with recombinant ovine leptin dissolved in incomplete Freund's adjuvant every 2 weeks for 8 weeks. In the case of the rabbits, a terminal bleed was obtained 4 weeks after the final boost. Egg collection from the immunized chickens commenced 2 weeks after the final boost. IgG was purified from rabbit serum using a Hi-Trap Protein G column (Amersham International plc, Amersham, Bucks, UK). The total IgG was subsequently affinity purified using an antigen column (Harlow \& Lane 1988). Recombinant ovine leptin was coupled to AminoLink Coupling gel (Pierce, Rockford, IL, USA) by cyanogen-bromide activation. Antibodies were eluted with $100 \mathrm{mM}$ glycine $(\mathrm{pH} 2 \cdot 5)$. IgY was extracted from the egg yolks using EGGstract IgY purification system (Promega, Southampton, Hants, UK). The IgY was affinity purified in a similar manner to the rabbit $\operatorname{IgG}$. The eluates were subsequently ammonium sulphate precipitated and dialysed against phosphate-buffered saline (PBS). The chicken-raised antibodies were subsequently biotinylated using the protein biotinylation module (Amersham International plc). The affinity purified IgGs and $\operatorname{IgYs}$ were tested for immunoreactivity against the recombinant ovine leptin and for cross-reactivity for suitability in the sandwich ELISA.

Procedure for the ELISA High-affinity 96-well plates (Nunc, Rostrup, Denmark) were coated with $100 \mu \mathrm{l}$ /well $0.05 \mathrm{M}$ carbonate/bicarbonate buffer, pH 9.6 (Sigma, Poole, Dorset), containing $1.3 \mu \mathrm{g} / \mathrm{ml}$ rabbit anti-ovine leptin affinity purified $\operatorname{IgG}$ for $30 \mathrm{~min}$ at $37^{\circ} \mathrm{C}$ and then overnight at $4{ }^{\circ} \mathrm{C}$. The plate was washed three times with 0.15 M PBS containing 0.05\% Tween-20 (PBS-T), using a plate washer (Dynex Multi-Reagent Washer; Dynex, Ashford, Middx, UK), and then blocked with $100 \mu \mathrm{l} /$ well PBS containing 3\% bovine serum albumin (BSA) (Sigma) for $1 \mathrm{~h}$ at $37^{\circ} \mathrm{C}$. Subsequent incubations were carried out at room temperature. Following a further three washes with PBS-T, $100 \mu \mathrm{l} /$ well plasma sample or recombinant ovine leptin standard (200-0.39 ng/ml) diluted in PBS-T containing 1\% BSA (PBS-TB) was added to the plate and incubated for $3 \mathrm{~h}$. After further washing three times with PBS-T, the plate was coated with $100 \mu \mathrm{l} /$ well biotinylated, affinity purified, chicken anti-leptin $\operatorname{Ig} Y$ $(1.8 \mu \mathrm{g} / \mathrm{ml})$ in PBS-TB and incubated for $1 \mathrm{~h}$. Next, the plate was washed three times with PBS-T as before, and incubated for $1 \mathrm{~h}$ with $100 \mu \mathrm{l} /$ well extravidin-horseradish peroxidase (Sigma) diluted 1:4000 in PBS-TB. After further washing three times with PBS-T and a final wash with PBS, the plate was developed by adding $200 \mu \mathrm{l} /$ well tetramethylbenzidine dihydrochloride substrate (Sigma) and incubating for $30 \mathrm{~min}$. The reaction was stopped by the addition of $50 \mu \mathrm{l} /$ well $_{2} \mathrm{SO}_{4}$. Absorbance was determined at $450 \mathrm{~nm}$ using a plate spectrophotometer (Dynex). The results were analysed using RMS software (Dynex) with a cubic spline fit of logged data.

\section{Protein extraction from placental and adipose tissue}

Placental cotyledon or maternal perirenal adipose tissue (day 128 of gestation) was homogenized in five times (w/v) extraction buffer $\left(100 \mathrm{mM} \mathrm{NH} \mathrm{NH}_{4} \mathrm{HCO}_{3}, 10 \mathrm{mM}\right.$ EGTA, $10 \mathrm{mM}$ EDTA, pH 9.4). The homogenate was then spun at $15000 \mathrm{~g}$ for $15 \mathrm{~min}$ at $4{ }^{\circ} \mathrm{C}$. Protein was quantified using the Bradford (1976) method with BSA as standard. The protein extract from the placental cotyledons was used for Western blotting. The leptin content of the protein extract from the adipose tissue was determined by the ovine-specific ELISA and expressed per $\mu$ g protein.

\section{Nuclease protection assay}

Total RNA was extracted from maternal perirenal adipose tissue (day 128: $\mathrm{M}, n=4: \mathrm{H}, n=5$ ) by a guanidinethiocyanate phenol method (Chomczynski \& Saachi 1987). The RNA was subsequently incubated with DNase I (Promega) in the presence of an RNase inhibitor for $30 \mathrm{~min}$ at $37^{\circ} \mathrm{C}$.

The oligonucleotide probe (antisense) for the ovine leptin gene was designed using the published sequence of ovine leptin (Genbank U84247). The sequence of the oligonucleotide was: 5'-GGTCATTAGATATTTGGAT CACATTTCTGGAAGGCAGACTGGCGAGAAAAA AAA-3' (193 to 238). Leptin gene expression was quantified with respect to $28 \mathrm{~S}$ gene expression. The sequence of the 28 S oligonucleotide was: 5'-CGTTCCCTATTAG TGGGTGAACAATCCAACGCTTGAAAAAAAA-3' . The oligonucleotides were labelled at the $5^{\prime}$ end with $\left[\gamma-{ }^{32} \mathrm{P}\right] \mathrm{ATP}$, catalysed by T4 polynucleotide kinase (Promega).

The nuclease protection assay was carried out with a commercial kit (Multi-NPA; Ambion, Austin, TX, USA). Briefly, labelled oligonucleotides were hybridized with RNA from maternal perirenal adipose tissue or placenta at $37^{\circ} \mathrm{C}$ for $16-18 \mathrm{~h}$. Unlabelled $28 \mathrm{~S}$ oligonucleotide was added to the hybridization reaction to ensure probe excess. Unhybridized probe was digested with a nuclease mixture (S1 Nuclease/RNase 1/RNase T1), supplied by Ambion. Digestion decreased the size of the leptin oligonucleotide 
probe from 54- to 46-mer and the $28 \mathrm{~S}$ oligonucleotide probe from 43- to 35-mer. The fragments were separated on a $12 \%$ urea polyacrylamide gel. The gel was subsequently vacuum dried and exposed to a phosphor storage Bio-Rad Imaging Screen (Bio-Rad, Hercules, CA, USA). The screen was scanned using a Bio-Rad Molecular Imager and the intensity of the bands signifying leptin and $28 \mathrm{~S}$ gene expression was quantified using Scion Image (Scion Corporation, Frederick, MD, USA). The ovine leptin gene expression was quantified relative to $28 \mathrm{~S}$ gene expression.

\section{RT-PCR}

Total RNA was isolated from placental cotyledons obtained at day 128 of gestation using an RNAqueous Kit (Ambion). The RNA was subsequently incubated with DNase I (Promega) in the presence of RNase inhibitor at $37^{\circ} \mathrm{C}$ for $30 \mathrm{~min}$. cDNA was generated by reverse transcription using the Superscript Preamplification system (Gibco/BRL, Paisley, Strathclyde, UK). The quality of the cDNA and mock cDNA was determined by the relative level of amplification of mouse $\beta$-actin. The primers for mouse $\beta$-actin gene were $5^{\prime}$-CTCTTTGA TGTCACGCACGATTTC- $3^{\prime}$ and $5^{\prime}$-ATCGTGGGC CGCTCTAGGCACC-3' which generated a $542 \mathrm{bp}$ product. Two sets of $\mathrm{cDNA}$ primers to the ovine leptin gene were designed. The sequence of the first set of cDNA primers was $5^{\prime}$-ACATTGGCAATCTACCAAC AGATC-3' (169 to 192) and 5'-CATGTCCTGTAGAG ACCCCTGTAG-3' (385 to 408, Genbank U84247) which generated a $240 \mathrm{bp}$ product. The sequence of the second set, which spans an intron, was 5'-AAGACGAT TGTCACCAGGATCAA-3' (43 to 65) and $5^{\prime}$-TCCAA ACCAGTGACCCTCTGTT-3' (98 to 119) which generated a $77 \mathrm{bp}$ product. The cDNA primers to the leptin receptor sequence which recognizes all known splice variants of the leptin receptor $(\mathrm{Ob}-\mathrm{R})$ were $5^{\prime}$-TGCC ACCAAATACAACATATGACT-3' (99 to 122) and 5'-CTTAGTTTCAACAACTGCCTCAGA-3' (176 to 199, Genbank U63719), $101 \mathrm{bp}$ product. The cDNA primers to the long form of the ovine leptin receptor, $\mathrm{Ob}-\mathrm{Rb}$, were $5^{\prime}$-GATGAGATGGTGCCAACAA CTA-3' (121 to 142$)$ and $5^{\prime}$-TGGGTTTCTATTTCC CATGATC-3' (407 to 128 , Genbank U62124), 308 bp product.

PCR was performed on a Hybaid Touchdown thermal cycler (Hybaid Ltd, Ashford, Middx, UK) using the following conditions: $\mathrm{Ob}$, primer set one $94{ }^{\circ} \mathrm{C}(4 \mathrm{~min})-$ 1 cycle; $94{ }^{\circ} \mathrm{C}(1 \mathrm{~min}), 58{ }^{\circ} \mathrm{C}(1 \mathrm{~min}), 72{ }^{\circ} \mathrm{C}(1 \mathrm{~min})-38$ cycles; $72{ }^{\circ} \mathrm{C}(10 \mathrm{~min})-1$ cycle. $\mathrm{Ob}$ primer set two $94{ }^{\circ} \mathrm{C}$ (4 min) - 1 cycle; $94{ }^{\circ} \mathrm{C}(1 \mathrm{~min}), 60{ }^{\circ} \mathrm{C}(1 \mathrm{~min}), 72{ }^{\circ} \mathrm{C}$ $(1 \mathrm{~min})-38$ cycles; $72^{\circ} \mathrm{C}(10 \mathrm{~min})-1$ cycle. $\beta$-actin, $\mathrm{Ob}-\mathrm{R}$ and $\mathrm{Ob}-\mathrm{Rb} 94^{\circ} \mathrm{C}(4 \mathrm{~min})-1$ cycle; $94{ }^{\circ} \mathrm{C}$ $(1 \mathrm{~min}), 55^{\circ} \mathrm{C}(1 \mathrm{~min}), 72{ }^{\circ} \mathrm{C}(1 \mathrm{~min})-35$ cycles; $72{ }^{\circ} \mathrm{C}$ (10 min) -1 cycle.
The PCR reaction (final volume $20 \mu \mathrm{l}$ ) contained $10 \mathrm{mM}$ Tris- $\mathrm{HCl}(\mathrm{pH} 9 \cdot 0), 50 \mathrm{mM} \mathrm{KCl}, 0 \cdot 01 \%$ Triton

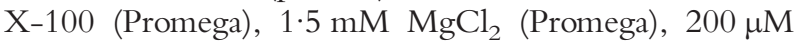
dNTPS (Promega), $5 \mu \mathrm{M}$ of each primer and $1.5 \mathrm{U}$ Taq polymerase (Promega). Agarose gel electrophoresis (2.5\%) in the presence of ethidium bromide confirmed the presence of a single band of the expected size for each of the PCR primer pairs.

\section{Immunocytochemistry}

Immunocytochemistry was performed on $5 \mu \mathrm{m}$ waxembedded sections of placental cotyledon, collected at day 128 of gestation, previously fixed overnight in $4 \%$ paraformaldehyde. The sections were deparaffinized using a xylene bath and then rehydrated in a graded series of alcohol washes. Staining was carried out using the DAKO EnVision+ System (DAKO, Cambridge, Cambs, UK). This system is based on a horseradish peroxidase-labelled polymer which is conjugated with a secondary antibody. Unlike other systems, avidin/biotin is not involved therefore eliminating any non-specific staining due to endogenous avidin/biotin activity. Briefly, tissue sections were incubated in DAKO peroxidase block to quench endogenous peroxide activity. After washing in PBS, nonspecific binding was blocked by incubating sections in normal serum for $20 \mathrm{~min}$. Tissue sections were incubated overnight at $4{ }^{\circ} \mathrm{C}$ with primary antibody. The primary antibody was raised, in rabbit, against recombinant ovine leptin (Gertler et al. 1998) and diluted 1:400. After further washing, the sections were incubated with DAKO horseradish peroxidase-labelled polymer and then staining completed by incubation with 3,3-diaminobenzidine (DAB+) substrate-chromogen (DAKO). Sections were counterstained with haematoxylin. Specific staining was confirmed by incubation with rabbit $\operatorname{IgG}$ instead of primary antibody.

\section{Western blotting}

Protein $(15 \mu \mathrm{g})$ extracted from placental cotyledon, collected at day 128 of gestation, was loaded onto a precast gel $(7 \cdot 5 \%)$ (Bio-Rad) and subjected to SDS-PAGE. The gel was electroblotted onto a nitro-cellulose membrane (Hybond C-extra; Amersham International plc) using a semidry electroblotter (Biometra, Göttingen, Germany). The membrane was blocked overnight at $4{ }^{\circ} \mathrm{C}$ in Trisbuffered saline (TBS) buffer, $\mathrm{pH} 7 \cdot 5$, (20 mM Tris/ $500 \mathrm{mM} \mathrm{NaCl}$ ) containing $0 \cdot 05 \%$ Tween-20 (TBS-T) and $10 \%$ skimmed milk powder. Subsequent incubations were carried out at room temperature. Next, the membrane was incubated with rabbit anti-mouse leptin receptor $(\mathrm{Ob}-\mathrm{Rb}$ ) serum (Linco Research, St Charles, MO, USA) at a dilution of $1: 100$ in TBS-T containing $3 \%$ skimmed milk powder for $2 \mathrm{~h}$. The membrane was then washed and incubated with anti-rabbit $\operatorname{IgG}$ 
conjugated to horseradish peroxidase (Scottish Antibody Production Unit, Edinburgh, UK; diluted 1:250) for $1 \mathrm{~h}$. After further washing in TBS-T, followed by a final wash in TBS, the protein bands were visualized by chemiluminescence with an ECL luminescence kit (Amersham International plc) and exposed to Hyper-film ECL (Amersham International plc) for 1-5 min according to the manufacturer's instructions. The size of the protein bands was determined using electrophoresis colour markers. Protein extracted from mouse placenta $(15 \mu \mathrm{g})$ was also run on the gel as a positive control.

\section{Data analysis}

Data are presented as means \pm s.E.M. and differences between nutritional treatments were analysed by Student's $t$-test. Linear regression and correlation coefficients were used to analyse the relationship between variables and to examine changes in leptin concentration over time. General linear modelling was used to analyse the effect of dietary treatment on variables. A probability of less than 0.05 was regarded as significant.

\section{Results}

\section{ELISA}

An ovine leptin-specific solid-phase sandwich ELISA was developed. The limit of sensitivity of the assay is $1-3 \mathrm{ng} / \mathrm{ml}$, which was sufficient to detect circulating maternal leptin concentrations in all nutritional treatments studied. The intra- and interassay coefficients of variation were 13.3 and $18.8 \%$, as determined from pooled ewe plasma samples; these were consistently in the linear part of the standard curve. Diluted ovine plasma exhibited good parallelism with the standard curve. Ovine plasma samples (MM group) spiked with recombinant ovine leptin (10 and $15 \mathrm{ng})$ gave recoveries of $95 \pm 6 \cdot 9 \%(n=3)$.

\section{Circulating leptin concentrations during ovine pregnancy}

Circulating leptin concentrations were studied to term in the four experimental groups (MM, HH, $\mathrm{MH}$ and $\mathrm{HM}$; Fig. 1). Overall at embryo transfer, leptin concentrations were similar in $\mathrm{MM}$ and $\mathrm{HH}$ dams (means \pm s.E.M. $4 \cdot 6 \pm 1 \cdot 12$ and $3 \cdot 1 \pm 0.49 \mathrm{ng} / \mathrm{ml}$ respectively, not significant (n.s.); Fig. 1a). By day 50 of pregnancy, leptin levels were significantly elevated in the $\mathrm{HH}$ versus the $\mathrm{MM}$ group $(7 \cdot 0 \pm 1 \cdot 07$ and $3 \cdot 3 \pm 0 \cdot 63 \mathrm{ng} / \mathrm{ml}, P<0 \cdot 02)$. This difference was maintained until term $(9 \cdot 8 \pm 1 \cdot 13$ and $3 \cdot 3 \pm 1 \cdot 4 \mathrm{ng} / \mathrm{ml}, P<0 \cdot 05)$.

Similar to the MM and $\mathrm{HH}$ groups, leptin concentrations were not significantly different between the $\mathrm{MH}$ and HM dams at embryo transfer $(4 \cdot 0 \pm 0.96$ and $7 \cdot 3 \pm 3 \cdot 48 \mathrm{ng} / \mathrm{ml}$ respectively, n.s.; Fig. $1 \mathrm{~b}$ and c). A
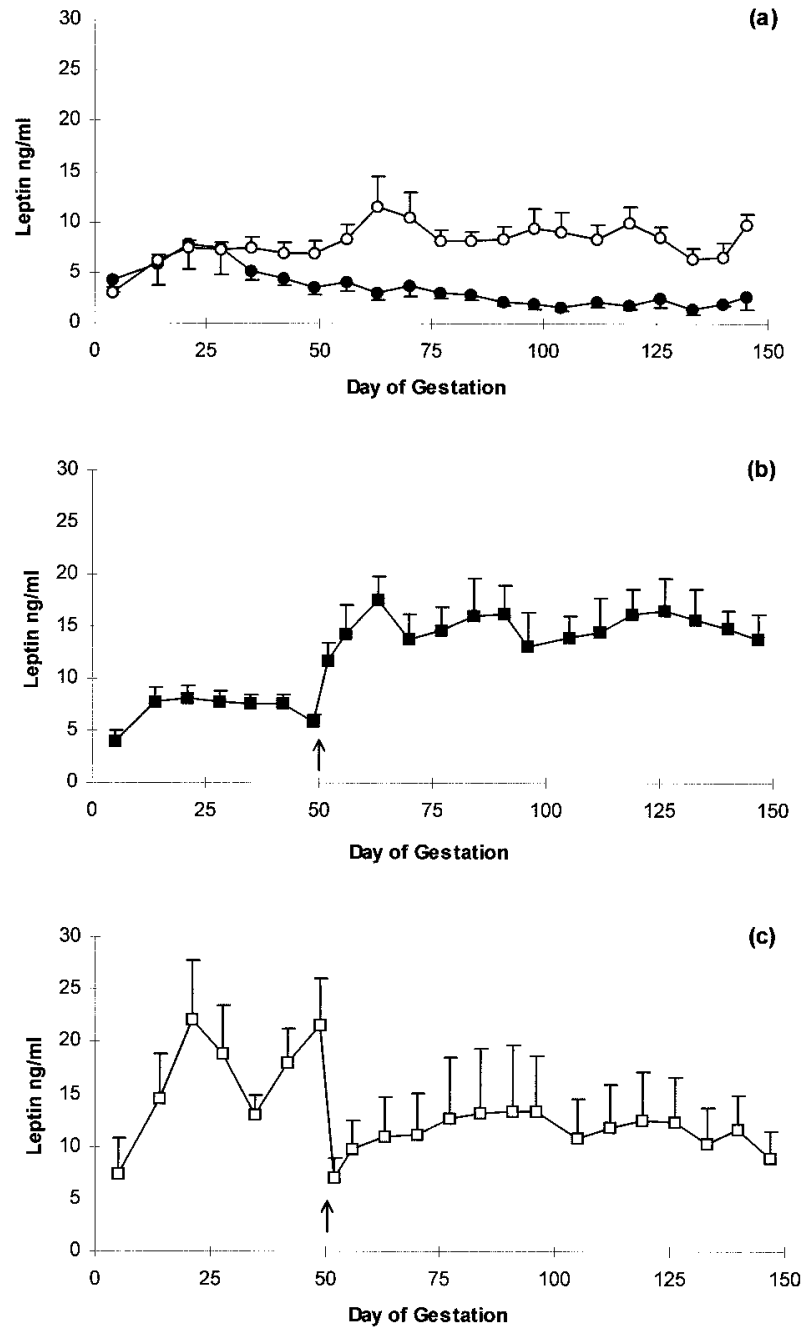

Figure 1 Circulating leptin concentrations throughout gestation in adolescent ewes. Nutritional treatments: (a) moderate intake (MM, $n=6)(\bigcirc)$, high intake $(\mathrm{HH}, n=7)(\bigcirc)$; (b) moderate intake to day 50 of gestation then switch to high intake $(\mathrm{MH}, n=7)(\boldsymbol{\square})$; (c) high intake to day 50 of gestation then switch to moderate intake (HM, $n=6)(\square)$. Results are mean values \pm S.E.M. (bars). The arrows in (b) and (c) indicate when the switch in dietary intake occurred.

sample measured on day 49 of gestation, before the nutritional switch occurred, showed that leptin concentrations were significantly higher in $\mathrm{HM}$ than in $\mathrm{MH}$ $(21.6 \pm 4.36$ and $5.9 \pm 0.63 \mathrm{ng} / \mathrm{ml}$ respectively, $P<0.02)$. Following the switch, leptin concentrations in the HM group fell markedly and leptin concentrations in the $\mathrm{MH}$ group increased. This change was readily detected in measurements taken at day 52 of gestation. Leptin concentrations had increased in the $\mathrm{MH}$ group to $11 \cdot 7 \pm 1 \cdot 81 \mathrm{ng} / \mathrm{ml}(P<0 \cdot 01$ compared with day 49$)$. This difference was still evident at term $(13.8 \pm 2.32 \mathrm{ng} / \mathrm{ml}$, $P<0 \cdot 02)$. In contrast, in the HM group, by day 52 of gestation leptin concentrations had decreased to 

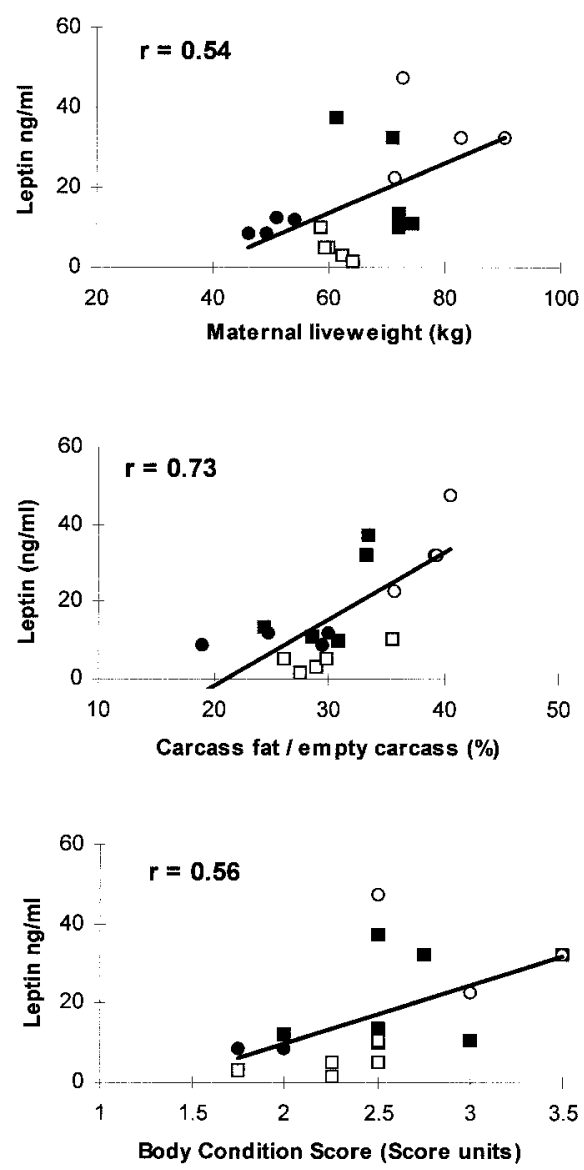
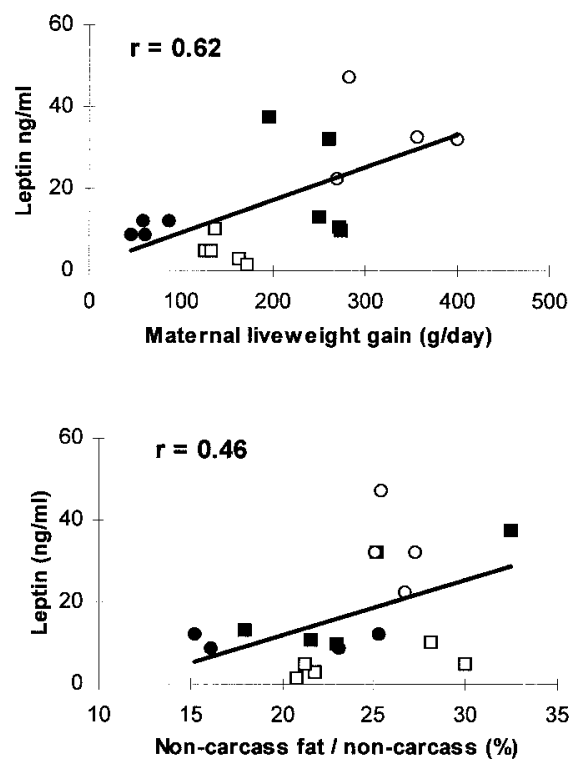

Figure 2 Relationship between maternal leptin concentrations, immediately prior to slaughter, and indices of body composition at day 104 of gestation. Nutritional treatments: moderate intake (MM) (O), high intake $(\mathrm{HH})(\bigcirc)$, moderate intake to day 50 of gestation then switch to high intake $(\mathrm{MH})(\boldsymbol{\square})$, high intake to day 50 of gestation then switch to moderate intake $\mathrm{HM}(\square)$.

$7 \cdot 0 \pm 1 \cdot 97 \mathrm{ng} / \mathrm{ml}(P=0 \cdot 02$ compared with day 49$)$, and at term leptin concentrations in this group were similar to day $52(8.9 \pm 2.53 \mathrm{ng} / \mathrm{ml}$, n.s. $)$. The data for the $\mathrm{MM}$ group show that there was a steady reduction in leptin concentrations over time. Linear regression analysis for each individual animal in this group indicated that there was an overall decrease in leptin concentrations. When analysed individually, five out of the six animals had a negative slope (mean regression coefficient of the slope: $-0 \cdot 0361$, mean standard error 0.0109).

As reported previously, maternal plasma glucose was measured three times weekly throughout pregnancy and non-esterified fatty acids (NEFA) and glucose were measured frequently over a $26-\mathrm{h}$ period starting on day 49 and day 99 of gestation (Wallace et al. 1999). Plasma glucose concentrations were significantly lower in the moderate intake groups, compared with the high intake groups throughout pregnancy and during the more detailed sampling period in days 49 and 99. NEFA concentrations were significantly higher in the moderate intake groups, compared with the high intake groups, during day 49 and day 99 of gestation (Wallace et al. 1999).

\section{Relationship between leptin and body composition}

A subset of ewes was slaughtered at day 104. When data were pooled across nutritional treatments, circulating leptin concentrations prior to slaughter were positively correlated with maternal liveweight, liveweight gain between days 4 and 104 of gestation, body condition score and maternal carcass fat content per empty carcass weight and non-carcass fat per non-carcass weight $(r=0 \cdot 46-0 \cdot 73$, $P<0.0006$ to $P<0.06$ ) (Fig. 2). As expected, the data for the $\mathrm{MH}$ and $\mathrm{HM}$ groups fell between the $\mathrm{MM}$ and $\mathrm{HH}$ groups. Similarly, at term, leptin concentrations were positively correlated with body condition score $(r=0 \cdot 43$, $P<0 \cdot 03$ ) and maternal liveweight gain between day 104 and term $(r=0.52, P<0 \cdot 007)$ (data not shown). When 
Table 1 Pregnancy outcome data for adolescent ewes delivering live young (Wallace et al. 1999). Nutritional treatments: $\mathrm{MM}$ moderate intake, $\mathrm{HH}$ high intake, $\mathrm{MH}$ moderate intake to day 50 of gestation then switch to high intake, HM high intake to day 50 of gestation then switch to moderate intake. Values are means \pm S.E.M.

\begin{tabular}{|c|c|c|c|c|}
\hline & \multicolumn{4}{|c|}{ Nutritional treatment } \\
\hline & MM & $\mathrm{HH}$ & $\mathrm{MH}$ & HM \\
\hline No. & 6 & 7 & 7 & 6 \\
\hline Lamb birth weight $(\mathrm{kg})^{\mathrm{a}}$ & $4 \cdot 9 \pm 0.57$ & $3 \cdot 0 \pm 0 \cdot 34$ & $3 \cdot 1 \pm 0 \cdot 27$ & $4 \cdot 5 \pm 0 \cdot 47$ \\
\hline Total placental weight $(g)^{b}$ & $457 \pm 75 \cdot 1$ & $258 \pm 33 \cdot 5$ & $310 \pm 28 \cdot 2$ & $373 \pm 31 \cdot 0$ \\
\hline Cotyledon weight $(\mathrm{g})^{\mathrm{a}}$ & $133 \pm 21 \cdot 1$ & $56 \pm 6 \cdot 1$ & $67 \pm 6 \cdot 3$ & $95 \pm 17 \cdot 3$ \\
\hline Cotyledon number ${ }^{\mathrm{a}}$ & $103 \pm 3 \cdot 4$ & $79 \pm 7 \cdot 8$ & $110 \pm 5 \cdot 2$ & $100 \pm 10 \cdot 7$ \\
\hline $\begin{array}{l}\text { Maternal liveweight at } \\
\text { term }(\mathrm{kg})\end{array}$ & $62 \cdot 0 \pm 0 \cdot 48$ & $79 \cdot 3 \pm 2 \cdot 15$ & $72 \cdot 4 \pm 1.28$ & $65 \cdot 4 \pm 0 \cdot 81$ \\
\hline $\begin{array}{l}\text { Maternal body condition } \\
\text { score at term }\end{array}$ & $2 \cdot 0 \pm 0 \cdot 18$ & $2 \cdot 9 \pm 0 \cdot 05$ & $2 \cdot 8 \pm 0 \cdot 05$ & $2 \cdot 3 \pm 0 \cdot 08$ \\
\hline
\end{tabular}

MM vs $\mathrm{HH}:{ }^{\mathrm{a} P}<0 \cdot 05,{ }^{\mathrm{b}} \mathrm{P}<0 \cdot 03$.

nutritional treatment was included as a factor in the general linear model, the effect of carcass fat/empty carcass weight on leptin remained significant $(P<0 \cdot 04)$. Whereas the effect of other indices of body composition became non-significant (day 104; maternal liveweight $P=0 \cdot 16$, liveweight gain $P=0 \cdot 21$, body condition score $P=0 \cdot 46$, non-carcass fat/non-carcass weight $P=0.07$ : term; liveweight gain $P=0.26$, body condition score $P=0.72$ ). However, the effect of nutritional treatment was significant for all traits (day 104; maternal liveweight $P=0 \cdot 007$, liveweight gain $P=0 \cdot 02$, body condition score $P=0 \cdot 02$, carcass fat/empty carcass weight $P=0.03$, non-carcass fat/non-carcass weight $P=0 \cdot 002$ : term; liveweight gain $P=0 \cdot 05$, body condition score $P=0 \cdot 03$ ).

\section{Relationship between leptin and pregnancy outcome}

Pregnancy outcome data for all treatment groups are shown in Table 1 (Wallace et al. 1999). At term, HH compared with $\mathrm{MM}$ intakes resulted in a significant reduction in lamb birthweight $(P<0 \cdot 05)$, total placental weight $(P<0 \cdot 03)$, fetal cotyledon weight $(P<0.05)$ and cotyledon number $(P<0 \cdot 05)$. Examining all four treatment groups together there was a trend towards a negative association, which did not reach statistical significance, between lamb birthweight, total placental weight and total cotyledon weight and circulating leptin concentrations prior to parturition (Fig. 3). However, when MM and $\mathrm{HH}$ groups were analysed together this negative relationship between leptin concentrations and lamb birthweight, total cotyledon number and total cotyledon weight reached statistical significance $(r=0.58-0.64, \quad P<0.05)$. When nutritional treatment was included in the general linear model, the effect of pregnancy outcome on leptin concentration became non-significant (four nutritional treatments; birth weight $P=0 \cdot 67$, placental weight $P=0 \cdot 46$, cotyledon weight $P=0.68$ : $\mathrm{MM}$ and $\mathrm{HH}$ groups only; birth weight $P=0 \cdot 69$, cotyledon number $P=0 \cdot 76$, cotyledon weight $P=0.73$ ). However, the effect of nutritional treatment was significant (four nutritional treatments; birth weight $P=0 \cdot 01$, placenta weight $P=0 \cdot 004$, cotyledon weight $P=0 \cdot 01$ : $\mathrm{MM}$ and $\mathrm{HH}$ groups only; birth weight $P=0 \cdot 02$, cotyledon number $P=0 \cdot 02$, cotyledon weight $P=0 \cdot 04)$. This suggests that the differences in pregnancy outcome seen across the nutritional groups are mainly due to nutrition.

\section{Leptin $m R N A$ and protein in maternal adipose tissue}

Leptin mRNA was detected by nuclease protection assay in all maternal perirenal adipose tissue samples examined (M $n=4, \mathrm{H} n=5$, day 128) (Fig. 4). Differences in the level of gene expression were detected when the two dietary treatments were compared. The $\mathrm{H}$ group had a significantly higher level of leptin mRNA compared with the $\mathrm{M}$ group. Leptin mRNA level, relative to $28 \mathrm{~S}$ rRNA, was $14 \cdot 0 \pm 2.53$ in the $\mathrm{H}$ group compared with $5 \cdot 5 \pm 0 \cdot 83$ in the $\mathrm{M}$ group $(P<0 \cdot 04)$. Indeed, there was a higher leptin protein content in the adipose tissue from the $\mathrm{H}$ group, as assessed by the ELISA. The leptin protein concentration of the perirenal adipose tissue samples from ewes in the M group $(n=6)$ was $0 \cdot 5 \pm 0 \cdot 05$ compared with $1 \cdot 1 \pm 0 \cdot 12 \mathrm{ng}$ leptin/ $\mu \mathrm{g}$ protein for the $\mathrm{H}$ group $(n=6)$ $(P<0 \cdot 005)$. These differences between the two dietary regimes in adipose tissue leptin mRNA and protein paralleled the changes observed in the maternal circulating leptin concentrations.

\section{The placenta as a source of leptin}

Leptin gene expression was not detected in the ovine placenta by the nuclease protection assay (Fig. 4), but we were able to detect leptin gene expression by RT-PCR (Fig. 5a). This suggests that leptin is expressed at very low 

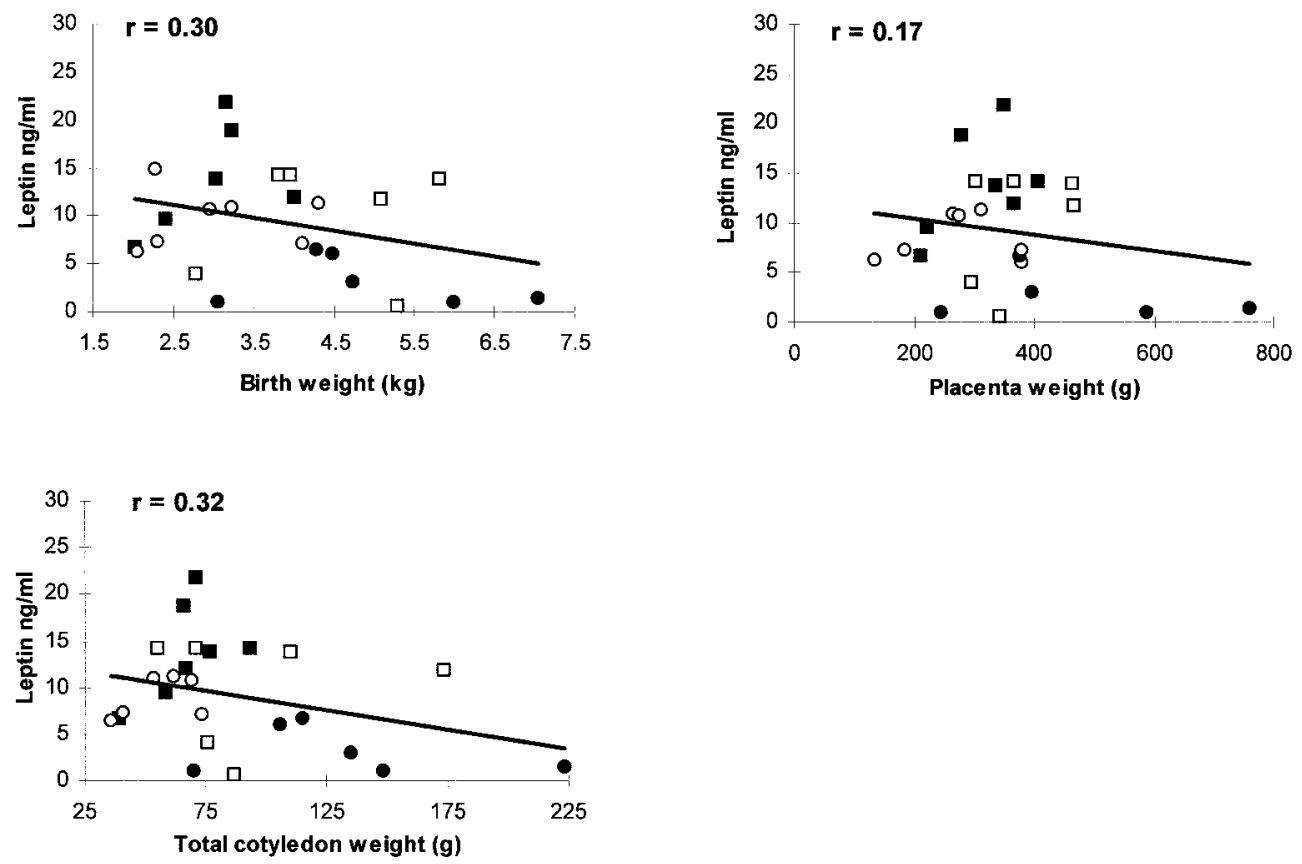

Figure 3 Relationship between circulating leptin concentrations and pregnancy outcome for adolescent ewes delivering live young. Nutritional treatments: moderate intake $(M M)(\bullet)$, high intake $(H H)(\bigcirc)$, moderate intake to day 50 of gestation then switch to high intake $(\mathrm{MH})(\boldsymbol{\square})$, high intake to day 50 of gestation then switch to moderate intake (HM) $(\square)$.

levels in the ovine placenta. Using immunocytochemistry, on wax-embedded placental sections, specific staining for leptin protein was observed (Fig. 5b). In particular, positive staining (brown colour) is clearly evident in the trophectoderm at both the maternal and fetal interface. Using RT-PCR, leptin receptor gene expression, Ob-R

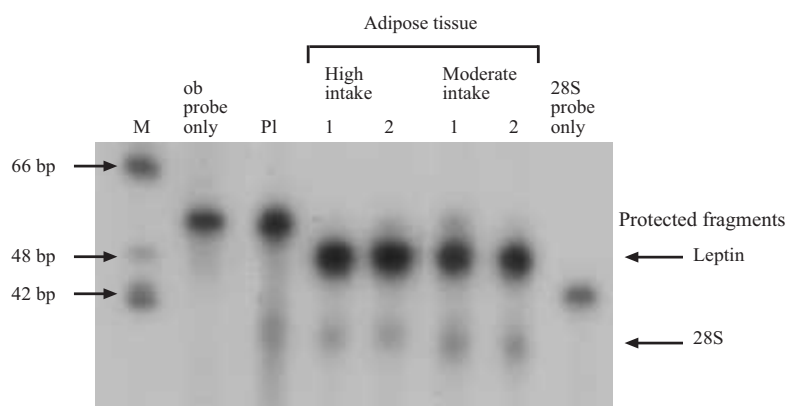

Figure 4 Ovine leptin mRNA and 28S rRNA in ovine perirenal adipose tissue and placenta at day 128 of gestation, detected by nuclease protection assay. Lanes: (1) size marker (bp), (2) control leptin probe, (3) Pl: placenta, moderate intake group, (4-5) adipose tissue, high intake group, (6-7) adipose tissue, moderate intake group and (8) control $28 \mathrm{~S}$ probe. The tissue samples were hybridized with leptin and $28 \mathrm{~S}$ probes and subsequently nuclease-digested. and $\mathrm{Ob}-\mathrm{Rb}$, was clearly evident in the ovine placenta (Fig. 5a). Western analysis revealed the presence of leptin receptor protein $(\mathrm{Ob}-\mathrm{Rb})$ in ovine placenta (Fig. 5c). A band was observed at $120 \mathrm{kDa}$ corresponding to $\mathrm{Ob}-\mathrm{Rb}$, a band was also observed in the mouse placenta (positive control) at the same position. Non-specific binding was evident at higher molecular weights.

\section{Discussion}

Using a newly developed sheep-specific sandwich ELISA and the pregnant adolescent sheep model, we were able to determine the circulating leptin concentrations throughout pregnancy in overfed and control normal-fed dams and to correlate these levels with leptin expression from adipose tissue, indices of body fat and pregnancy outcome. First, we observed that circulating leptin concentrations throughout gestation were related to dietary intake. It was clear that overfeeding resulted in a significant increase in leptin concentration and it was also apparent that circulating leptin concentrations are strongly related to body fat, suggesting that the increase in leptin concentrations in the overfed animals is linked to the increase in body fat and the corresponding increased production of leptin by the adipose tissue. The observed relationship with body fat is 
a

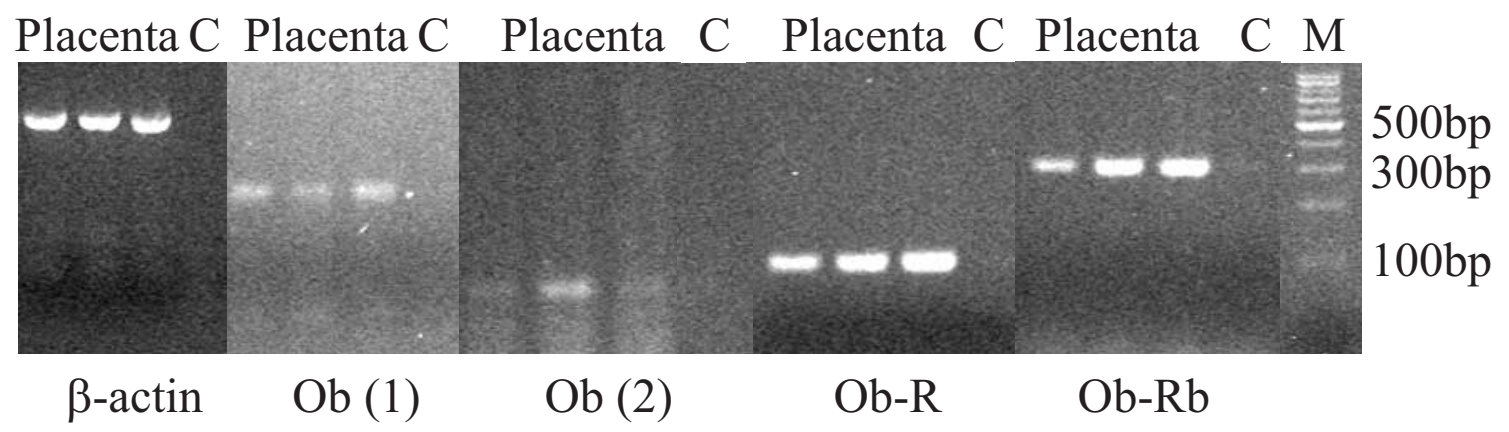

$\mathrm{b}$
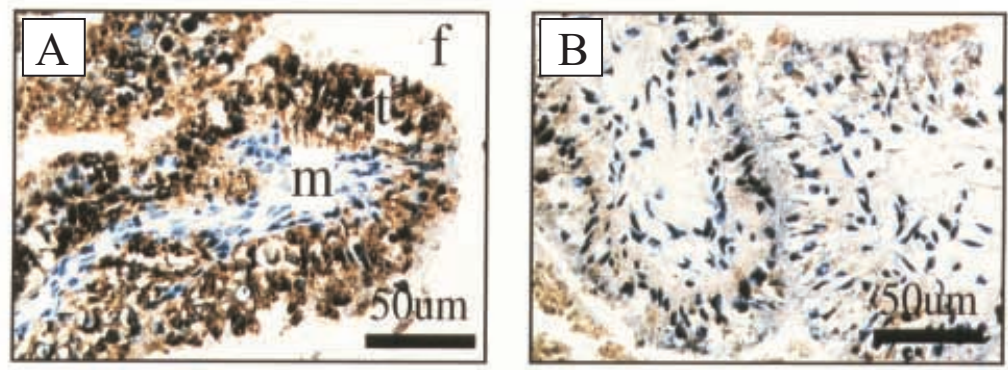

$\mathrm{C}$

Placenta

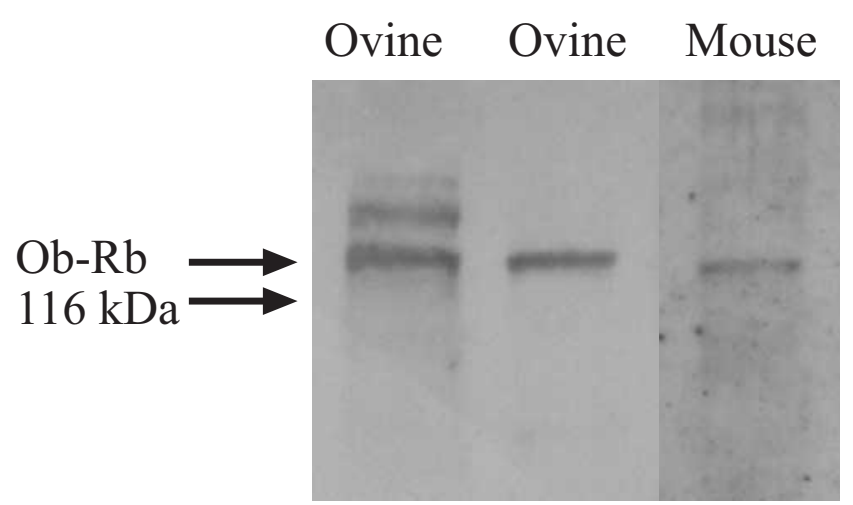

Figure 5 Ovine placenta as a source of leptin (day 128 of gestation, moderate intake group). (a) RT-PCR expression analysis of leptin and leptin receptor. Lanes: (placenta) three placenta samples, (C) no CDNA, (M) molecular marker (100 bp ladder). The expression of leptin $(\mathrm{Ob})$ was compared with the common extracellular domain of the leptin receptor (Ob-R) and the long splice variant $(\mathrm{Ob}-\mathrm{Rb})$. $\beta$-actin amplification was used as a control. No bands were observed with the mock cDNA (data not shown) or in the absence of CDNA. RT-PCR was carried out with two sets of cDNA ovine leptin primers, primer set 2 spans an intron. (b) Immunolocalization of leptin. $\mathrm{f}$, fetal aspect; $\mathrm{m}$, maternal aspect; $\mathrm{t}$, trophectoderm. Placental ovine sections were incubated with (A) leptin antiserum, (B) IgG control. Immunoreaction was visualized by DAB + and sections were counterstained with haematoxylin (bar $=50 \mu \mathrm{m})$. (c) Western blot analysis of leptin receptor protein $(\mathrm{Ob}-\mathrm{Rb})$ in two ovine placenta and one mouse placenta sample. Protein $(15 \mu \mathrm{g})$ was loaded onto each lane; band observed at $120 \mathrm{kDa}$ corresponds to Ob-Rb. $116 \mathrm{kDa}$ marker is shown. 
consistent with previous data in non-pregnant sheep by Blache et al. (2000), which demonstrates a relationship between leptin and body fat in this species, as in rodents and humans (Maffei et al. 1995, Considine et al. 1996). Blache et al. (2000) found a strong correlation between plasma leptin and back fat thickness, explaining 30\% of the variation in leptin concentrations. Similarly, Delavaud et al. (2000) observed a strong positive relationship, in non-pregnant sheep, between plasma leptin and body weight, body condition score and body fatness. Up to 35\% of the variation in circulating leptin was explained by variations in body fat. Indeed, in our study, $27 \%$ of the variation in the leptin concentrations was explained by the subjective assessment of body condition score, while actual carcass fat measurements (expressed per empty carcass) explained $51 \%$. We are unable to distinguish whether dietary intake or the changed body compositions, due to the nutritional treatments, was the primary factor influencing the circulating leptin concentrations. However, Delavaud et al. (2000) reported that feeding level explained between 14 and $17 \%$ of the variation in leptin concentration in non-pregnant sheep. This suggests that, although nutritional intake significantly affects leptin concentrations, body fatness explains a larger proportion of the variation.

Leptin was initially regarded as a satiety signal regulating the size of fat depots. A negative feedback loop occurs between the brain and adipose tissue regulating the production of the hormone. Rodent studies have shown that fasting results in a decrease in leptin mRNA expression and circulating leptin concentrations which then increase with subsequent refeeding (Trayhurn et al. 1995, Hardie et al. 1996). In the pregnant adolescent sheep model, dietary intakes of the overnourished ewes $(\mathrm{HH}$ group) were maintained throughout the last two thirds of gestation (Wallace et al. 1999). The results presented here indicate that the increase in fat mass is responsible for the increase in plasma leptin concentrations in these animals, compared with moderately fed controls. Therefore, it would appear that, despite the increase in leptin, food intake was not affected, suggesting that the negative feedback mechanisms between the brain and adipose tissue do not respond to the chronic incremental changes in plasma leptin and that the animals are resistant to the increasing leptin, at least with regards to food intake. In the moderately fed group, circulating leptin remained steady initially, and then towards the end of pregnancy there was evidence of an overall decrease in leptin concentrations. This occurred during late pregnancy at a time when the ewes become catabolic and fat mobilization occurs. It would appear that the leptin concentrations reflect this switch from an anabolic to a catabolic state, again reflecting changes in fat mass.

A rapid response of the leptin system to changes in food intake and energy balance was observed in the nutritional switch-over study. Circulating leptin levels in this particu- lar ovine model appeared to respond quickly to changes in food intake independently of changes in adipose tissue mass which occurred subsequently. The change in food intake affected maternal leptin concentrations by over $65 \% 2$ days after the dietary switch occurred. Kumar et al. (1998) have shown that changes in food intake, as a result of fasting, resulted in alterations in ovine adipose tissue leptin gene expression. After $48 \mathrm{~h}$ of fasting, genetically selected fat and lean lines of Coopworth sheep showed a decrease in leptin gene expression of eight- to ninefold, six- to ninefold and fourfold in back, omental and perirenal fat respectively. The changes in leptin concentrations in response to alterations in dietary intake, seen in the present study, mirrored the changes that occurred in maternal body weight and body condition score (Wallace et al. 1999).

Maternal endocrine status was also studied in these animals (see Wallace et al. 1999). Plasma insulin was measured throughout pregnancy, and this hormone closely followed the plane of nutrition, with the high intake groups having significantly higher concentrations compared with moderately fed controls. More particularly, in the switchover groups, maternal insulin concentrations followed a similar pattern to leptin, with the dietary switch causing a rapid change in concentrations. At term, irrespective of treatment group, there was a positive correlation between maternal leptin and insulin $(r=0.45, P<0 \cdot 03)$, dietary intake was also involved in this relationship (general linear modelling, $P=0 \cdot 02)$. The relationship between insulin and leptin has been extensively investigated and it is apparent from these studies that leptin and insulin closely interact (for review see Harris 2000). It has been proposed that a dual hormone feedback system operates between these two hormones (Kieffer \& Habener 2000). Key features of this relationship include leptin's inhibitory effect on insulin production and secretion, both peripherally and through leptin receptors in pancreatic $\beta$-cells (Emilsson et al. 1997), leptin's ability to increase glucose uptake by muscle (Kamohara et al. 1997, Cusin et al. 1998), and the stimulation of leptin production by insulin. It is therefore possible that the rapid and marked changes in leptin concentrations seen in this study in response to the dietary switch are mediated by insulin. A potential regulator of leptin secretion during pregnancy is placental oestrogen, although at this stage the effects of oestrogen on leptin remain unclear (Henson \& Castracane 2000).

In both the moderately fed and overfed group we observed no peak in circulating leptin towards the end of pregnancy. This is in marked contrast to that reported in humans and rodents, with a threefold increase towards the end of pregnancy in humans (Hardie et al. 1997) and rats (Chien et al. 1997) and a 25-fold increase in pregnant mice (Tomimatsu et al. 1997). However, in one study in which age-matched pregnant rats were used there was no increase in circulating leptin during pregnancy, with circulating leptin levels reflecting leptin gene expression in adipose tissue (Terada et al. 1998). Similarly, it is 
important to note that in the highly controlled ovine model used in the present study the dams were of equivalent age at the time of embryo transfer.

Adipose tissue is the main source of circulating leptin. However, as outlined in the Introduction, there are a number of reports demonstrating leptin expression in human and rodent placenta (Hoggard et al. 1997, Masuzaki et al. 1997, Terada et al. 1998). The function of placental leptin is at present unknown, but the hormone may be involved in nutrient partitioning to the fetus. In this study we were unable to detect leptin gene expression in the ovine placenta by nuclease protection assay, but could detect leptin gene expression by the more sensitive technique of RT-PCR. This indicates that leptin is expressed at very low levels in the ovine placenta, levels which are probably too low to be contributing significantly to the maternal circulation. The significance, if any, of this low level of leptin expression is not clear. Similar levels of leptin expression have been reported for rodent placenta, but it should be noted that human placental expression of leptin appears to be higher.

In contrast to low levels of leptin expression, high levels of leptin protein can be detected in rodent, human and pig placenta (Hoggard et al. 1997, Ashworth et al. 2000). In keeping with this and despite the low level of leptin gene expression in the ovine placenta, the immunocytochemistry studies presented here clearly show leptin protein present at significant levels in the maternal and fetal interface of the ovine placenta. One possible explanation for this is leptin binding to its receptor rather than direct expression from the placenta. Our data support this idea since expression of both $\mathrm{Ob}-\mathrm{R}$ and $\mathrm{Ob}-\mathrm{Rb}$ and the presence of $\mathrm{Ob}-\mathrm{Rb}$ protein in the ovine placenta were observed, suggesting that leptin has an, as yet, undetermined signalling role in the placenta. More detailed colocalization studies are needed to confirm this observation. However, it should also be noted that posttranscriptional regulation of leptin expression has been reported (Kirchgessner et al. 1997, Ranganathan et al. 1998) and this could also be a possible explanation for the presence of a significant amount of leptin protein in the ovine placenta despite the low leptin gene expression.

Finally, we have demonstrated, in this adolescent pregnant ewe model, a clear negative association between leptin in the maternal circulation and fetal birth weight, placental/cotyledon weight and number. Given the putative signalling role of leptin in the placenta this requires further investigation. No correlation between maternal circulating leptin and birth weight has, as yet, been reported in humans (Schubring et al. 1997). In conclusion, the negative association with birth weight and placentome number and weight is clearly of interest and further work is required to establish whether the leptin system plays a regulatory role in the metabolic adaptations required during pregnancy to ensure optimum fetal growth and development.

\section{Acknowledgements}

We thank Dr A Gertler for the kind gift of recombinant ovine leptin, Dr R Lea for assistance with the immunocytochemistry and Dr S Ferris, Biomathematics and Statistics Scotland for statistical advice. This work was funded by the Scottish Executive Rural Affairs Department and is a contribution from the Aberdeen Centre for Energy Regulation and Obesity (ACERO).

\section{References}

Ahima RS, Dushay J, Flier SN, Prabakaran D \& Flier JS 1997 Leptin accelerates the onset of puberty in normal female mice. Journal of Clinical Investigation 99 391-395.

Ashworth CJ, Hoggard H, Thomas L, Mercer JG, Wallace JM \& Lea RG 2000 Placental leptin. Reviews of Reproduction 5 18-24.

Atkinson T, Fowler VR, Garton GA \& Lough AK 1972 A rapid method for the determination of lipid in animal tissue. Analyst 97 $562-568$

Bado A, Levasseur S, Attoub S, Kermorgant S, Laigneau J, Boortoluzzi M, Moizo L, Lehy T, Guerre-Millo, Le Marchand-Brustel Y \& Lewin MJM 1998 The stomach is a source of leptin. Nature 394 790-793.

Bi S, Gavrilova O, Gong DW, Mason MM \& Reitman M 1997 Identification of a placental enhancer for the human leptin gene. Journal of Biological Chemistry 272 30583-30588.

Blache D, Tellam RL, Chagas LM, Blackberry MA, Vercoe PE \& Martin GB 2000 Level of nutrition affects leptin concentration in plasma and cerebrospinal fluid in sheep. Journal of Endocrinology 165 625-637.

Bodner J, Ebenbichler CF, Wolf HJ, Muller-Holzner E, Stanzl U, Gander R, Huter O \& Patsch JR 1999 Leptin receptor in human term placenta: in situ hybridization and immunohistochemical localization. Placenta 20 677-682.

Bradford MM 1976 A rapid and sensitive method for the quantitation of microgram quantities of protein utilizing the principle of protein-dye binding. Analytical Biochemistry 72 248-254.

Chehab FF, Lim ME \& Lu R 1996 Correction of the sterility defect in homozygous obese female mice by treatment with the human recombinant leptin. Nature Genetics 12 318-320.

Chehab FF, Mounzih K, Lu R \& Lim ME 1997 Early onset of reproductive function in normal female mice treated with leptin. Science 275 88-90.

Chien EK, Hara M, Rouard M, Yano H, Phillippe M, Polonsky KS \& Bell GI 1997 Increase in serum leptin and uterine leptin receptor messenger RNA levels during pregnancy in rats. Biochemical and Biophysical Research Communications 237 476-480.

Chomczynski P \& Saachi N 1987 Single-step method of RNA isolation by acid guanidinium thiocyanate-phenol-chloroform extraction. Analytical Biochemistry 162 156-159.

Considine RV, Sinha MK, Heiman ML, Kriauciunas A, Stephen TW, Nyce MR, Ohannesian JP, Marco CC, McKee LJ, Bauer TL \& Caro JF 1996 Serum immunoreactive-leptin concentrations in normal-weight and obese humans. New England Journal of Medicine 334 292-295.

Cusin I, Zakrzewska KE, Boss O, Muzzin P, Giacibino JP, Ricquier D, Jeanrenaud B \& Rohner-Jeanrenaud F 1998 Chronic central leptin infusion enhances insulin-stimulated glucose metabolism and favors the expression of uncoupling proteins. Diabetes $\mathbf{4 7}$ 1014-1019.

Delavaud C, Bocquier F, Chilliard Y, Keisler DH, Gertler A \& Kann G 2000 Plasma leptin determination in ruminants: effect of nutritional status and body fatness on plasma leptin concentration 
assessed by specific RIA in sheep. Journal of Endocrinology 165 519-526.

Emilsson V, Liu YL, Cawthorne MA, Morton NM \& Davenport M 1997 Expression of the functional leptin receptor mRNA in pancreatic islets and direct inhibitory action of leptin on insulin secretion. Diabetes 46 313-316.

Gavrilova O, Barr V, Marcus-Samuels B \& Reitman M 1997 Hyperleptinemia of pregnancy associated with the appearance of a circulating form of the leptin receptor. Journal of Biological Chemistry 272 30546-30551.

Gertler A, Simmons J \& Keisler DH 1998 Large-scale preparation of biologically active recombinant ovine obese protein (leptin). FEBS Letters 422 137-140.

Hardie LJ, Rayner DV, Holmes S \& Trayhurn P 1996 Circulating leptin levels are modulated by fasting, cold exposure and insulin administration in lean but not Zucker (fa/fa) rats as measured by ELISA. Biochemical and Biophysical Research Communications 223 660-665.

Hardie L, Trayhurn P, Abramovich D \& Fowler P 1997 Circulating leptin in women: a longitudinal study in the menstrual cycle and during pregnancy. Clinical Endocrinology 47 101-106.

Harlow E \& Lane D 1988 Rabbit antibody affinity purification. In Antibodies: A Laboratory Manual. Cold Spring Harbor: Cold Spring Harbor Press.

Harris RBS 2000 Leptin - much more than a satiety signal. Annual Review of Nutrition 20 45-75.

Henson MC \& Castracane VD 2000 Leptin in pregnancy. Biology of Reproduction 63 1219-1228.

Henson MC, Swan KF \& O’Neill JS 1998 Expression of placental leptin and leptin receptor transcripts in early pregnancy and at term. Obstetrics and Gynecology 92 1021-1028.

Hoggard N, Hunter L, Duncan JS, Williams LM, Trayhurn P \& Mercer JG 1997 Leptin and leptin receptor mRNA and protein expression in the murine fetus and placenta. PNAS 94 11073-11078.

Hoggard N, Hunter L, Trayhurn P, Williams LM \& Mercer JG 1998 Leptin and reproduction. Proceedings of the Nutrition Society $\mathbf{5 7}$ 421-427.

Hoggard N, Hunter L, Lea RG, Trayhurn P \& Mercer JG 2000 Ontogeny of the expression of leptin and its receptor in the murine fetus and placenta. British Journal of Nutrition 88 317-326.

Kamohara S, Burcelin R, Halaas JL, Freidman JM \& Charron MJ 1997 Acute stimulation of glucose metabolism in mice by leptin treatment. Nature 389 374-377.

Kieffer TJ \& Habener JF 2000 The adipoinsular axis: effects of leptin on pancreatic $\beta$-cells. American Journal of Physiology 278 E1-E14.

Kirchgessner TG, Uysal KT, Wiesbrock SM, Marino MW \& Hotamisligil GS 1997 Tumor necrosis factor- $\alpha$ contributes to obesity related hyperleptinemia by regulating leptin release from adipocytes. Journal of Clinical Investigation 100 2777-2782.

Kumar B, Francis SM, Suttie JM \& Thompson MP 1998 Expression of obese mRNA in genetically lean and fat selection lines of sheep. Comparative Biochemistry and Physiology 120 543-548.

Lage M, Garcia-Mayor RV, Tome MA, Cordido F, Valle-Inclan F, Considine RV, Caro JF, Dieguez C \& Casanueva FF 1999 Serum leptin in women throughout pregnancy and the postpartum period and in women suffering spontaneous abortion. Clinical Endocrinology $50211-216$

Lea RG, Howe D, Hannah L, Bonneau O, Hunter L \& Hoggard N 2000 Placental leptin in normal, diabetic and fetal growth-retarded pregnancies. Molecular Human Reproduction 6 763-769.
Lewandowski K, Horn R, O'Callaghan CJ, Dunlop D, Medley GF, O'Hare P \& Brabant G 1999 Free leptin, bound leptin, and soluble leptin receptor in normal and diabetic pregnancies. Journal of Clinical Endocrinology and Metabolism 84 300-306.

Maffei M, Halaas J, Ravussin E, Pratley RE, Lee GH, Zhang Y, Fei H, Kim S, Lallone R, Ranganathsan S, Kern PA \& Friedman JM 1995 Leptin levels in human and rodent: measurement of plasma leptin and ob mRNA in obese and weight-reduced subjects. Nature Medicine 1 1155-1161.

Masuzaki H, Ogawa Y, Sagawa N, Hosoda K, Matsumoto T, Mise T, Nishimura H, Yoshimasa Y, Tanaka I, Mori T \& Nakao K 1997 Nonadipose tissue production of leptin: leptin as a novel placenta-derived hormone in humans. Nature Medicine $\mathbf{3}$ 1029-1033.

Ranganathan S, Maffei M \& Kern PA 1998 Adipose tissue ob mRNA expression in humans: discordance with plasma leptin and relationship with adipose TNF $\alpha$ expression. Journal of Lipid Research 39 724-730.

Russel AJF, Doney JM \& Gunn RG 1969 Subjective assessment of body fat in live sheep. Journal of Agricultural Science 72 451-454.

Schubring C, Kiess W, Englaro P, Rascher W, Dotsch J, Hanitsch S, Attanasio A \& Blum WF 1997 Levels of leptin in maternal serum, amniotic fluid, and arterial and venous cord blood: relation to neonatal and placental weight. Journal of Clinical Endocrinology and Metabolism 82 1480-1483.

Terada Y, Yamakawa K, Sugaya A \& Toyoda N 1998 Serum leptin levels do not rise during pregnancy in age-matched rats. Biochemical and Biophysical Research Communications 253 841-844.

Tomimatsu T, Yamaguchi M, Murakami T, Ogura K, Sakata M, Mitsuda N, Kanzaki T, Kurachi H, Irahara M, Miyake A, Shima K, Aono T \& Murata Y 1997 Increase of mouse leptin production by adipose tissue after mid pregnancy: gestational profile of serum leptin concentration. Biochemical and Biophysical Research Communications 240 213-215.

Trayhurn P, Thomas MEA, Duncan JS \& Rayner DV 1995 Effects of fasting and refeeding on ob gene expression in white adipose tissue of lean and obese (ob/ob) mice. FEBS Letters 368 488-490.

Wallace JM, Aitken RP \& Cheyne MA 1996 Nutrient partitioning and fetal growth in rapidly growing adolescent ewes. Journal of Reproduction and Fertility 107 183-190.

Wallace JM, Bourke DA, Aitken RP \& Cruickshank MA 1999 Switching maternal dietary intake at the end of the first trimester has profound effects on placental development and fetal growth in adolescent ewes carrying singleton fetuses. Biology of Reproduction 61 101-110.

Wallace JM, Bourke DA, Aitken RP, Palmer RM, Da Silva P \& Cruickshank MA 2000 Relationship between nutritionallymediated placental growth restriction and fetal growth, body composition and endocrine status during late gestation in adolescent sheep. Placenta 21 100-108.

Wang J, Liu R, Hawkins M, Barzilai N \& Rossetti L 1998 A nutrient-sensing pathway regulates leptin gene expression in muscle and fat. Nature 393 684-688.

Received in final form 26 January 2001

Accepted 14 February 2001 